\title{
Why Does Enamel in Klk4-Null Mice Break above the Dentino-Enamel Junction?
}

\author{
James P. Simmer ${ }^{\mathrm{a}}$ Yuanyuan $\mathrm{Hu}^{\mathrm{a}}$ Amelia S. Richardson ${ }^{\mathrm{a}} \quad$ John D. Bartlett ${ }^{\mathrm{b}}$ \\ Jan C.-C. Hu ${ }^{\text {a }}$ \\ ${ }^{a}$ Department of Biologic and Materials Sciences, University of Michigan School of Dentistry, Ann Arbor, Mich., and \\ ${ }^{b}$ Department of Cytokine Biology, The Forsyth Institute, Cambridge, Mass., USA
}

\section{Key Words}

Amelogenesis • Proteases - Teeth • Ameloblasts •

Scanning electron microscopy $\cdot$ lac $Z$ histostaining

\begin{abstract}
Background: The enamel layer of kallikrein 4 (Klk4)-null mice has a normal thickness and a decussating pattern of enamel rods, but it contains residual enamel proteins, is less highly mineralized, and fractures in its deepest part just above the dentino-enamel junction (DEJ). The plane of fracture is puzzling because the deepest enamel is deposited earliest and, through the action of the secretory stage enamel protease (Mmp20), is the most mature part of the enamel layer at the time of the onset of Klk4 expression. Objectives: To characterize the planes of fracture in Mmp20-and Klk4-null mice and to localize KIk4 expression in developing teeth. Methods: Klk4- and Mmp20-null mice were sacrificed at 7 weeks and their mandibular incisors were characterized by scanning electron microscopy. $K l k 4^{+/ l a c z}$ mice were mated with $K I k 4^{+/ l a c z}$ mice. Offspring were genotyped by polymerase chain reaction. $K l k 4^{+/+}, K l k 4^{+/ l a c Z}$, and $K l k 4^{l a c Z / l a c Z}$ (null) littermates on postnatal days $5,8,11$, and 14 were processed for $\beta$-galactosidase histochemistry. Results: The enamel layer fractures at the DEJ in Mmp20-null mice, and fractures occur in enamel above the DEJ in Klk4-null mice. Klk4 is not expressed by secretory-stage ameloblasts, murine odonto-
\end{abstract}

blasts beneath the secretory stage, or maturation-stage ameloblasts. Klk4 is specifically expressed by transition and maturation-stage ameloblasts. Conclusions: The breakage of enamel near the DEJ in Klk4-null mice is not due to a failure of odontoblasts to express Klk4, but it relates to a progressive hypomineralization of enamel with depth.

Copyright $\odot 2011$ S. Karger AG, Basel

\section{Introduction}

Matrix metalloproteinase 20 (Mmp20) and kallikrein 4 (Klk4) are secreted proteases that degrade enamel proteins [Bartlett and Simmer, 1999]. Mmp20 generates the enamel protein cleavage products that accumulate in secretory-stage enamel [Ryu et al., 1999; Iwata et al., 2007; Nagano et al., 2009; Chun et al., 2010]. Klk4 degrades enamel proteins during the transition and maturation

\section{Abbreviations used in this paper}

DEJ dentino-enamel junction

Klk4 kallikrein 4

Mmp20 matrix metalloproteinase 20

SEM scanning electron microscopy

\section{KARGER}

๑) 2011 S. Karger AG, Basel

Fax +4161306 1234

E-Mail karger@karger.ch

www.karger.com
Accessible online at: www.karger.com/cto
Dr. James P. Simmer

Department of Biologic and Materials Sciences

University of Michigan Dental Research Lab

1210 Eisenhower Place, Ann Arbor, MI 48108 (USA)

Tel. +1 734975 9318, E-Mail jsimmer@ umich.edu 


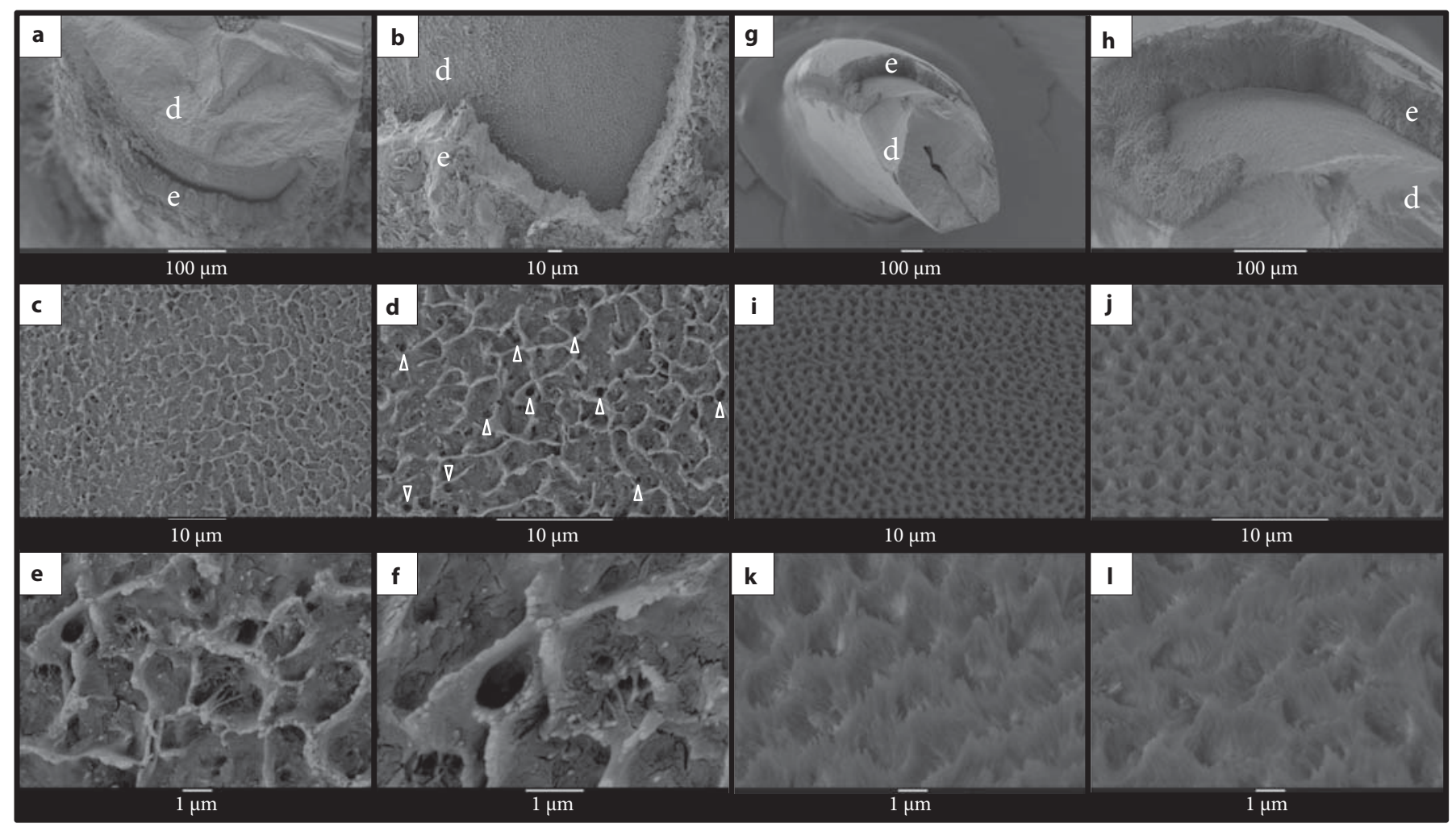

Fig. 1. SEM of mandibular incisors broken at the level of the alveolar bone crest. The Mmp20-null (a-f) and Klk4-null (g-I) incisors both make enamel that tends to fracture at or near the DEJ. $\mathbf{a}-\mathbf{h}$ At a low magnification it is shown that the enamel nearest to the split dentin surface has entirely or nearly entirely broken away. c-I Broken surfaces at a higher magnification. The level of the split is clearly different in the 2 mice. Mmp20-null incisors break at the
DEJ. The floor of the cleaved surface is clearly dentin, with an occasional dentinal tubule exposed (arrowheads). Klk4-null incisors break in the deepest layer of enamel just above the DEJ, with rows of circular vacancies left by the lost enamel rods. Jagged edges along the crests of the interrod enamel are the outlines of needle-like enamel crystals. $\mathrm{d}=$ Dentin; $\mathrm{e}=$ enamel.

\section{Materials and Methods}

\section{Scanning Electron Microscopy}

Mandibular incisors (3 each) from 7-week-old Mmp20- and Klk4-null mice were fractured at the level of the labial alveolar crest and mounted on metallic stubs using conductive carbon cement, degassed in a vacuum desiccator overnight, and sputtercoated with an Au-Pd film. The samples were imaged at the University of Michigan Microscopy and Image Analysis Laboratory (Ann Arbor, Mich., USA) using an Amray EF 1910 scanning electron microscope (SEM) operating at an accelerating voltage of $5 \mathrm{kV}$.

\section{Mouse Breeding}

$K l k 4^{+/ l a c Z}$ mice were mated with $K l k 4^{+/ l a c Z}$ mice. Offspring were genotyped by polymerase chain reaction [Simmer et al., 2009]. $K l k 4^{+/+}, K l k 4^{+/ l a c Z}$, and $K l k 4^{\text {lacZ/lacZ }}$ (null) littermates on postnatal days $5,8,11$, and 14 were processed for $\beta$-galactosidase histochemistry.
Our objectives in this study were (1) to better characterize the level that shears and (2) to determine if Klk4 is normally expressed by mouse odontoblasts. 

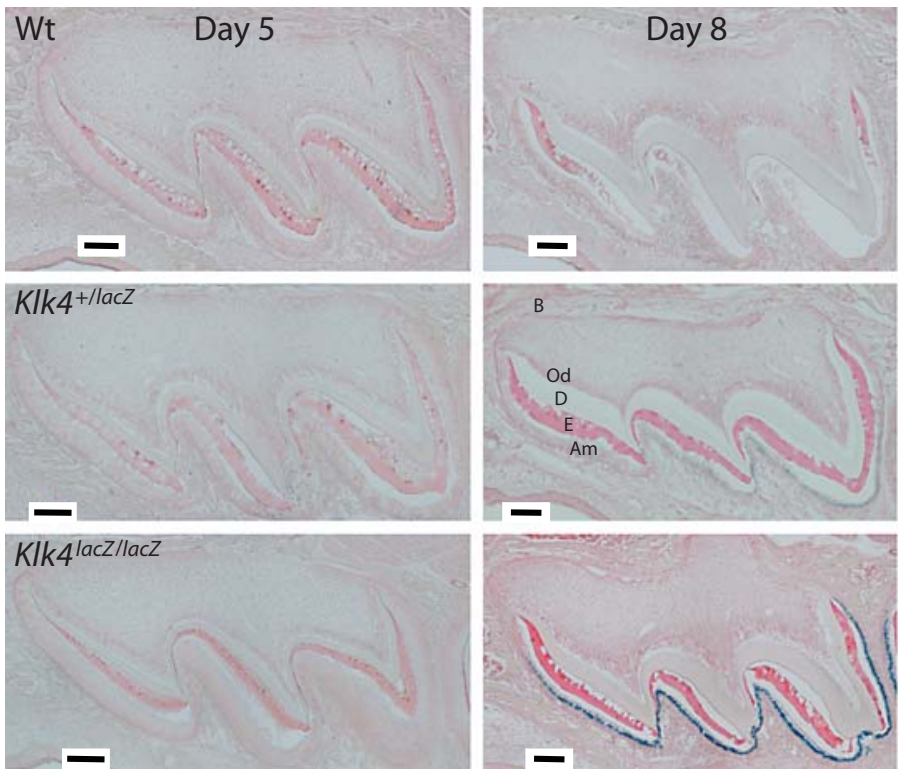

Fig. 2. LacZ histochemistry showing nuclear localized $\beta$-galactosidase activity where Klk4 is normally expressed. At the 5-hour incubation used, no endogenous (lysosomal) $\beta$-gal activity was observed and the wild-type $(\mathrm{Wt})$ mice were negative. In mouse

Tissue Processing for Histochemistry

Mouse heads were quickly dissected of skin, cut in half, and fixed by immersion in $4 \%$ paraformaldehyde $(\mathrm{pH} 7.3)$ in $1 \times \mathrm{PBS}$ overnight at $4^{\circ} \mathrm{C}$; they were then washed in $1 \times$ PBS $4-5$ times (every $0.5-1 \mathrm{~h}$ ) at $4^{\circ} \mathrm{C}$. The tissues were decalcified by immersion in 1 liter of $4.13 \%$ EDTA ( $\mathrm{pH} 7.3$ ) with agitation, changed every other day at $4^{\circ} \mathrm{C}$ (day 5: 8-9 days of decalcification, day 8: 19-21 days of decalcification, day 11: 21 days of decalcification, and day 14: 30 days of decalcification), and then washed in $1 \times$ PBS 4-5 times (every $0.5-1 \mathrm{~h}$ ) with 1 overnight wash at $4^{\circ} \mathrm{C}$. The tissues were immersed in $15 \%$ sucrose $(1-2 \mathrm{~h}$ ) followed by $30 \%$ sucrose (3-4 h) at $4^{\circ} \mathrm{C}$ for cryoprotection and then embedded in optimal cutting temperature media and stored at $-80^{\circ} \mathrm{C}$. The blocks were cryosectioned at $8 \mu \mathrm{m}$ at -20 to $-22^{\circ} \mathrm{C}$ on a Leica cryostat. Slides were stored at $-80^{\circ} \mathrm{C}$ until staining.

\section{X-Gal Staining}

Slides were removed from $-80^{\circ} \mathrm{C}$, immediately treated with glutaraldehyde fixative $(0.1 \mathrm{M}$ HEPES, $1.25 \mathrm{~mm}$ EGTA, $2 \mathrm{~mm}$ $\mathrm{MgCl}_{2}$, and $0.5 \%$ glutaraldehyde, $\mathrm{pH} 7.3$ ), and then washed with $0.1 \mathrm{M}$ HEPES and $2 \mathrm{mM} \mathrm{MgCl}_{2}$ (pH 7.3) 3 times for $5 \mathrm{~min}$. The slides were stained with X-gal solution [0.1 M HEPES, $1 \mathrm{~mm}$ $\mathrm{MgCl}_{2}, 5 \mathrm{~mm}$ potassium ferrocyanide, $5 \mathrm{mM}$ potassium ferricyanide, $2 \%$ Triton X-100, and $1 \mathrm{mg} / \mathrm{ml} \mathrm{X-gal} \mathrm{substrate} \mathrm{(Roche),} \mathrm{pH}$ 8.0] for $5 \mathrm{~h}$ or overnight at $45^{\circ} \mathrm{C}$ and then washed in $1 \times \mathrm{PBS}$ several times and counterstained with $0.1 \%$ (w/v) Nuclear Fast Red, coverslipped with Aquamount, and imaged using a Nikon Eclipse TE300 inverted microscope.
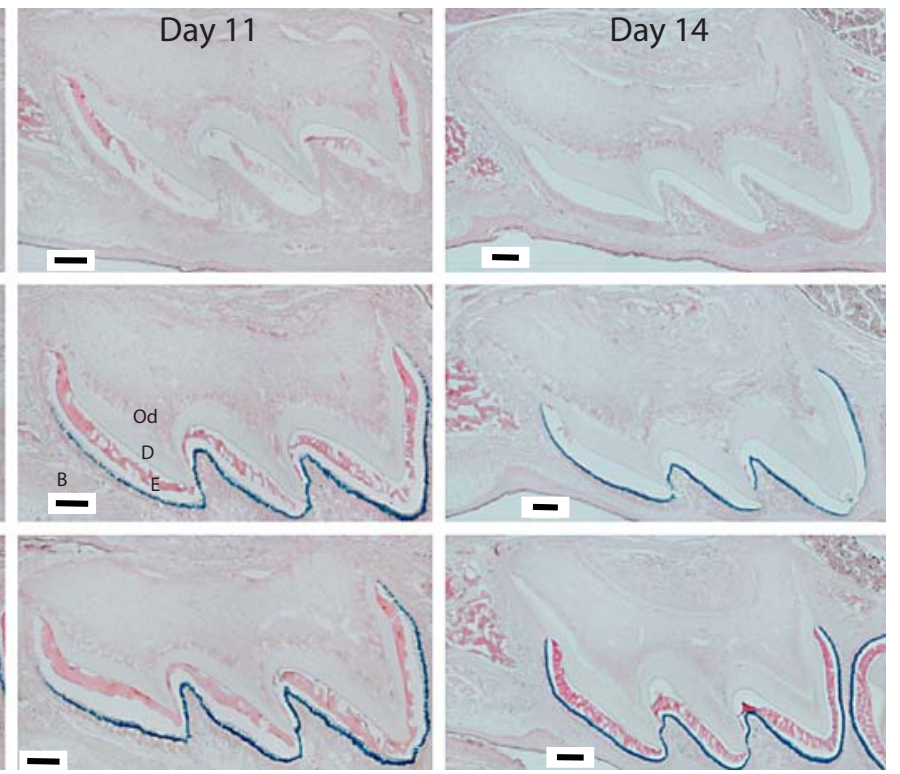

molars, a positive signal was only observed in transition and maturation ameloblasts. No expression was observed in odontoblasts. $\mathrm{B}=$ Bone; $\mathrm{Od}=$ odontoblasts; $\mathrm{D}=$ dentin; $\mathrm{E}=$ enamel; $\mathrm{Am}=$ ameloblasts. Scale bars $=100 \mu \mathrm{m}$.

\section{Results and Discussion}

We fractured mandibular incisors from Mmp20- and Klk4-null mice at the level of the alveolar crest to remove the erupted portion of the tooth that had been altered by masticatory forces and to create a freshly fractured surface in the most mature portion of the incisor that was about to erupt. The incisors were notched on the concave (dentin) side with a rotating disc and the 2 ends of the incisor were bent outward, causing the dentin to fracture roughly in a plane perpendicular to the tangent of the tooth surface for the full thickness of the dentin. The fracture spread along the dentino-enamel junction (DEJ) or near it for a short distance and then broke through the full thickness of the enamel on a path perpendicular to the tangent of the tooth surface. SEMs were used to make a visual interpretation of where the tooth surface fractured (fig. 1).

At low magnification, it appeared that the enamel and dentin of the Mmp20- (fig. 1a, b) and Klk4-null (fig. 1g, h) mice had delaminated at the level of the DEJ, but closer examination of the Mmp2O (fig. 1c-f) and Klk4 (fig. 1i-l) fractured incisor surfaces showed important and revealing differences.

The fractured surface of the Mmp20-null mouse incisor displayed thin, plate-like mineral projecting upwards, 

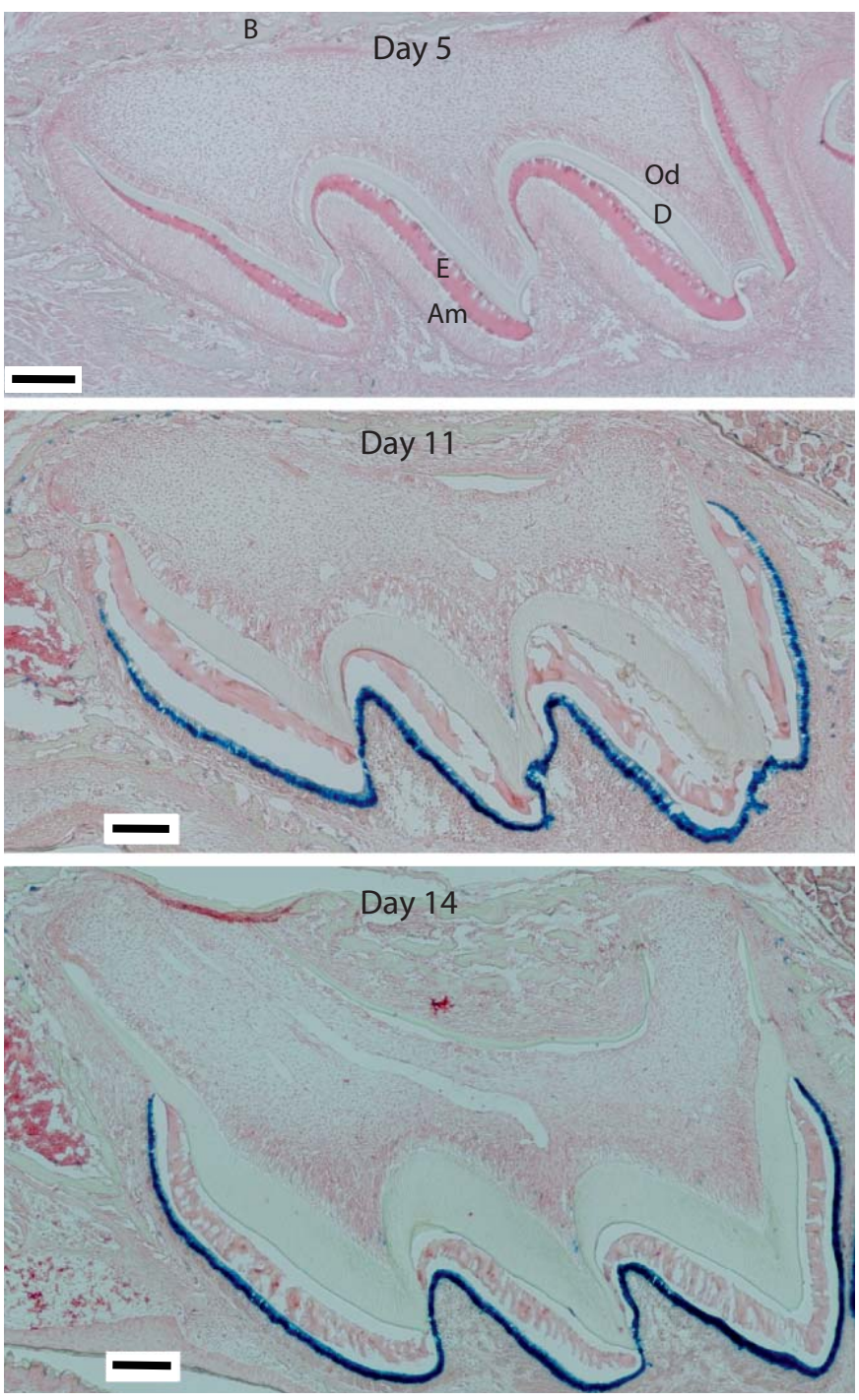

Fig. 3. LacZ histochemistry of Klk4-null mice molars after overnight incubation with the X-gal substrate. This experiment shows the limits of sensitivity of the $\beta$-galactosidase knockin strategy for Klk4. The staining in maturation ameloblasts is very strong and extends beyond the nuclei. A few sporadic nonameloblasts show staining probably due to detection of endogenous $\beta$-galactosidase activity. At no stage of crown formation are odontoblasts positive for Klk4 expression. B = Bone; Od = odontoblasts; $\mathrm{D}$ = dentin; $\mathrm{E}=$ enamel; $\mathrm{Am}=$ ameloblasts. Scale bars $=100 \mu \mathrm{m}$.

perpendicular to the surface that resembled the ruined walls of an archeological site (fig. 1c-f). The individual rooms or cells made by these projections were not aligned in rows and seemed to be relatively uniform in size. The floor was occasionally perforated by holes less than $1 \mu \mathrm{m}$ in diameter which were likely the ends of dentinal tubules. The overall impression was similar to SEMs of the villous surface of mantle dentin just prior to the onset of enamel deposition [Fejerskov and Thylstrup, 1986].

The fractured surface in the Klk4-null mouse incisor showed a field of interrod enamel perforated by linear arrays of holes $\sim 1 \mu \mathrm{m}$ in diameter that were vacancies left by loss of enamel rods that pulled out and fractured away with the rest of the enamel layer. The position of the fracture was the same as what we had previously observed in Klk4-null mouse molars at 7 weeks, which had fractured naturally following their eruption into function [Simmer et al., 2009]. The outline of individual, elongated enamel crystals is apparent along the crests of the interrod material projecting upward from the mineral walls separating the rod vacancies.

Separation of enamel from dentin is not surprising in the Mmp20-null mouse because Mmp20 is normally expressed and secreted during DEJ formation [Begue-Kirn et al., 1998; Hu et al., 2002], and formation of the DEJ is disturbed in Mmp20-null mice [Beniash et al., 2006]. Klk4, however, is not expressed until the enamel layer has reached full thickness, long after the DEJ has formed $[\mathrm{Hu}$ et al., 2000a, b; Simmer et al., 2004]. PCR analyses of developing pig molars detected Klk4 mRNA in odontoblasts, suggesting that Klk4 might be delivered to the DEJ by odontoblastic processes and account for the highly mineralized enamel just above the DEJ [Fukae et al., 2002]. Klk4 mRNA in mouse odontoblasts, however, has not been consistently observed by in situ hybridization analyses. In this study we used a Klk4 knockout/NLSlacZ knockin reporter to specifically monitor Klk4 expression in developing teeth [Simmer et al., 2009].

Bacterial $\beta$-galactosidase activity from the knockin gene is favored over lysosomal $\beta$-gal by incubating the tissue sections with substrate (X-gal) at $\mathrm{pH} 8$. When overincubation is performed to detect trace expression from the knockin, the mouse nuclear localization signal fused to the bacterial $\beta$-galactosidase helps distinguish expression from the knockin gene in the nucleus from endogenous activity in the lysosomes [Dymecki, 1996; Hu et al., 2008].

Developing first molars at days 5, 8, 11, and 14 were analyzed by lac $Z$ histochemistry. The X-gal-to-indigo reaction catalyzed by $\beta$-galactosidase (the lac $Z$ product) was specifically detected in maturation-stage ameloblasts in the Klk4-null mice at days 8, 11, and 14 (fig. 2). No positive staining was detected in wild-type first molars at any time point (negative control), and no staining was detected in day-5 first molars as amelogenesis had not yet advanced to the transition or maturation stages. Positive staining was observed in maturation stage ameloblasts in $K l \mathrm{k} 4^{+/ l a c Z}$ and $K l k 4^{l a c Z / l a c Z}$ first molars at days 8, 11, and 14, although 
the signal was barely discernable in the $K l \mathrm{k} 4^{+/ l a c Z}$ mice at day 8 . No staining was observed in odontoblasts at any time point. All signals were restricted to the nucleus of positive cells affirming that the indigo staining was specifically the result of NLS-lacZ knockin expression and not endogenous (lysosomal) $\beta$-galactosidase.

The sensitivity in this study appeared equal to those of our previous in situ hybridization analyses of Klk4 mRNA in mouse first molars but with better specificity (less background) [Hu et al., 2002]. We show 5-hour incubations without background that limit staining to the ameloblast nuclei. Overnight incubation showed light staining of spo- radic odontoblast nuclei (fig. 3) but stained beyond the nuclei in ameloblasts. Odontoblast expression of Klk4 in mouse is trace and unlikely to be physiologically relevant.

We conclude that breakage of enamel near the DEJ in Klk4-null mice is not due to a failure of odontoblasts to express $\mathrm{Klk} 4$, but it relates to a progressive hypo-mineralization of enamel with depth [Smith et al., 2011].

\section{Acknowledgements}

This research were supported by National Institutes of Health grants DE019775 (J.P.S.) and DE016276 (J.D.B.).

\section{References}

Bartlett, J.D., J.P. Simmer (1999) Proteinases in developing dental enamel. Crit Rev Oral Biol Med 10: 425-441.

-Begue-Kirn, C., P.H. Krebsbach, J.D. Bartlett, W.T. Butler (1998) Dentin sialoprotein, dentin phosphoprotein, enamelysin and ameloblastin: tooth-specific molecules that are distinctively expressed during murine dental differentiation. Eur J Oral Sci 106: 963 970 .

Beniash, E., Z. Skobe, J.D. Bartlett (2006) Formation of the dentino-enamel interface in enamelysin (MMP-20)-deficient mouse incisors. Eur J Oral Sci 114(suppl 1): 24-29, discussion 39-41, 379.

Caterina, J.J., Z. Skobe, J. Shi, Y. Ding, J.P. Simmer, H. Birkedal-Hansen, J.D. Bartlett (2002) Enamelysin (matrix metalloproteinase 20)-deficient mice display an amelogenesis imperfecta phenotype. J Biol Chem 277: 49598-49604.

Chun, Y.H., Y. Yamakoshi, F. Yamakoshi, M. Fukae, J.C. Hu, J.D. Bartlett, J.P. Simmer (2010) Cleavage site specificity of MMP-20 for secretory-stage ameloblastin. J Dent Res 89: $785-790$.

Dymecki, S. (1996) A modular set of Flp, FRT and lacZ fusion vectors for manipulating genes by site-specific recombination. Gene 171: 197-201.

Fejerskov, O., A. Thylstrup (1986) Dental enamel; in Mjor, I., O. Fejerskov (eds): Human Oral Embryology and Histology. Copenhagen, Munksgaard, pp 50-89.

-Fukae, M., T. Tanabe, T. Nagano, H. Ando, Y. Yamakoshi, M. Yamada, J.P. Simmer, S. Oida (2002) Odontoblasts enhance the maturation of enamel crystals by secreting EMSP1 at the enamel-dentin junction. J Dent Res 81 : 668-672.

-Hart, P.S., T.C. Hart, M.D. Michalec, O.H. Ryu, D. Simmons, S. Hong, J.T. Wright (2004) Mutation in kallikrein 4 causes autosomal recessive hypomaturation amelogenesis imperfecta. J Med Genet 41: 545-549.
Hu, J.C., Y. Hu, C.E. Smith, M.D. McKee, J.T. Nagano, T., A. Kakegawa, Y. Yamakoshi, S. Wright, Y. Yamakoshi, P. Papagerakis, G.K. Hunter, J.Q. Feng, F. Yamakoshi, J.P. Simmer (2008) Enamel defects and ameloblastspecific expression in Enam knock-out/lacz knock-in mice. J Biol Chem 283: 10858 10871.

Hu, J.C., O.H. Ryu, J.J. Chen, T. Uchida, K. Wakida, C. Murakami, H. Jiang, Q. Qian, C. Zhang, V. Ottmers, J.D. Bartlett, J.P. Simmer (2000a) Localization of EMSP1 expression during tooth formation and cloning of mouse cDNA. J Dent Res 79: 70-76.

-Hu, J.C., X. Sun, C. Zhang, S. Liu, J.D. Bartlett, J.P. Simmer (2002) Enamelysin and kallikrein-4 mRNA expression in developing mouse molars. Eur J Oral Sci 110: 307-315.

-Hu, J.C., C. Zhang, X. Sun, Y. Yang, X. Cao, O. Ryu, J.P. Simmer (2000b) Characterization of the mouse and human PRSS17 genes, their relationship to other serine proteases, and the expression of PRSS17 in developing mouse incisors. Gene 251: 1-8.

Iwata, T., Y. Yamakoshi, J.C. Hu, I. Ishikawa, J.D. Bartlett, P.H. Krebsbach, J.P. Simmer (2007) Processing of ameloblastin by MMP-20. J Dent Res 86: 153-157.

Kim, J.W., J.P. Simmer, T.C. Hart, P.S. Hart, M.D. Ramaswami, J.D. Bartlett, J.C. Hu (2005) MMP-20 mutation in autosomal recessive pigmented hypomaturation amelogenesis imperfecta. J Med Genet 42: 271-275.

Lee, S.K., F. Seymen, H.Y. Kang, K.E. Lee, K. Gencay, B. Tuna, J.W. Kim (2010) MMP20 hemopexin domain mutation in amelogenesis imperfecta. J Dent Res 89: 46-50.

Meredith, R.W., J. Gatesy, J. Cheng, M.S. Springer (2010) Pseudogenization of the tooth gene enamelysin (MMP20) in the common ancestor of extant baleen whales. Proc Biol Sci, E-pub ahead of print. Tsuchiya, J.C. Hu, K. Gomi, T. Arai, J.D. Bartlett, J.P. Simmer (2009) Mmp-20 and Klk4 cleavage site preferences for amelogenin sequences. J Dent Res 88: 823-828.

Ozdemir, D., P.S. Hart, O.H. Ryu, S.J. Choi, M. Ozdemir-Karatas, E. Firatli, N. Piesco, T.C. Hart (2005) MMP20 active-site mutation in hypomaturation amelogenesis imperfecta. J Dent Res 84: 1031-1035.

Papagerakis, P., H.K. Lin, K.Y. Lee, Y. Hu, J.P. Simmer, J.D. Bartlett, J.C. Hu (2008) Premature stop codon in MMP20 causing amelogenesis imperfecta. J Dent Res 87: 56-59.

Ryu, O.H., A.G. Fincham, C.C. Hu, C. Zhang, Q. Qian, J.D. Bartlett, J.P. Simmer (1999) Characterization of recombinant pig enamelysin activity and cleavage of recombinant pig and mouse amelogenins. J Dent Res 78: 743-750.

Ryu, O., J.C. Hu, Y. Yamakoshi, J.L. Villemain, X. Cao, C. Zhang, J.D. Bartlett, J.P. Simmer (2002) Porcine kallikrein-4 activation, glycosylation, activity, and expression in prokaryotic and eukaryotic hosts. Eur J Oral Sci 110: 358-365.

Simmer, J.P., Y. Hu, R. Lertlam, Y. Yamakoshi, J.C. Hu (2009) Hypomaturation enamel defects in Klk4 knockout/LacZ knockin mice. J Biol Chem 284: 19110-19121.

Simmer, J.P., X. Sun, Y. Yamada, C.H. Zhang, J.D. Bartlett, J.C.-C. Hu (2004) Enamelysin and kallikrein-4 expression in the mouse incisor; in Kobayashi, I., H. Ozawa (eds): Biomineralization: Formation, Diversity, Evolution and Application - Proceedings of the 8th International Symposium on Biomineralization, Niigata, Japan, September 2528, 2001. Hadano, Tokai University Press, pp 348-352.

Smith, C.E., A.S. Richardson, Y. Hu, J.D. Bartlett, J.C.-C. Hu, J.P. Simmer (2011): Effects of loss of function of kallikrein 4 on mineralization of enamel: comparison to mice lacking matrix metalloproteinase 20. J Biol Chem, Epub ahead of print, PMID: 21454549. 